\title{
Anti-inflammatory Activity of Methanoilc and Ethanolic Extracts of Citrus sinensis peel (L) Osbeck on Carrageenan induced Paw Oedema in Wistar rats
}

\author{
${ }^{* 1}$ OSARUMWENSE .P.O
}

\author{
${ }^{I}$ Department of Chemical sciences, Ondo State University of Science and Technology, Okitipupa, Ondo, Nigeria \\ ${ }^{I}$ Corresponding Author: E-mail: Osarodion.peter@yahoo.com;Tel: 08056350793
}

\begin{abstract}
Aqueous ethanoic and methanolic extracts of Citrus Sinensis Peel were investigated for antiinflammatory activity in carrageenan induced paw oedema in wistar rats, and compared to a positive control drug, Indomethacin. These extracts were given(IP) in a concentration of 20 , and $70 \mathrm{mg} / \mathrm{kg}$ with extract with a concentration whichshowed maximum(95\%) inhibition on carrageenan induced rat paw oedema. The effect was significantly higher than that of the standard drug indomethacin (93\%).Methanol extract with a concentration of $40 \mathrm{mg} / \mathrm{kg}$ produced $95 \%$ inhibition, which was also high as compared to the standard drug. Ethanolic extracts with doses of $20 \mathrm{mg} / \mathrm{kg}$ and $40 \mathrm{mg} / \mathrm{kg}$ produce less percentage of inhibition as compared to the standard drug Indomethacin. CJASEM

https://dx.doi.org/10.4314/jasem.v21i6.37
\end{abstract}

Key words: Citrus Sinensis, Anti-inflammation, Carrageenan, Peels, anti-inflammatory, ethanolic extract.

Many members of the Citrus genus are well known by the medicinal, Physiological and pharmacological activities including antimicrobial, antioxidant, anticancer and hypoglycemic activities (Ladaniya, 2008).

Citrus sinensis (L) Osbeck (Navel Orange) is a hybrid of two citrus species: Citrus maxima and Citrus reticulate (Saleemetal, 2010). The plant contains many medicinally active components from different classes including coumarins, carotenoid, flavonoids (Ortunoetal, 2006) and essential oil (Singh et al,2010).

Many medicinal properties of orange peel extracts, such as against colic, upset stomach, cancer, diuretic, cormunative, immune-enhancing, stomachich, tonic to digestive system, immune system and skin has been lested(Sapnaetal, 2016). It is also used to treat and prevent vitamin deficiencies, cold, flu and scurvy and helping to fight vita and bacterial infections(Grossoetal, 2013).

Antibacterial effects of orange peel have also been demonstrated in the literature. (Mehmood etal,2015). Orange peel extract was also found to be effective against Klebsiella pneumonia(Akdemiretal, 2015).

It also exhibits insecticidal properties against mosquito, cockroach and housefly(Ezeonuetal, 2001).The presence of polymethoxy flavones, namely nobiletin,heptamethoxy flavones and tangeretin contributes to the antifungal properties of the plant(Ortunoetal, 2006).

According to Haiquing, Anti-inflammatory activity of Citrus sinensis is due to the presence of polymethoxyflavones. The polymethoxy flavones of content, expeciallynobiletin, appears to be responsible for the anti-inflammatory activities of certain citrus peel extracts (Haiquing et al., 2004).Sweet orange oil is a byproduct of the juice industry produced by pressing the peel. It consist of about 90\% d-limonene (Omodamiro et al., 2013).

Citrus sinensis is widely known for health benefits and have found to produce antimicrobial effects, hence current research was planned to determine the anti-inflammatory effects of Citrus sinensis inwistar rats.

\section{MATERIALS AND METHODS}

Plant Materials: Fresh peel of citrus sinensis was collected from uselu market in Benin City, Edo state, Nigeria. It was identified at the Botany Department, Faculty of life science, University of Benin, Benin City where a voucher number 1758 is deposited. The peels were initially rinsed with distilled water, air dried in the laboratory under shade and ground into powder.

Preparation of Plant Extracts: The powdered mass of $1000 \mathrm{~g}$ of Citrus sinensis was extracted by soxhlet apparatus (Quickfit, England) using ethanol and methanol. The extract was concentrated under reduced pressure in a natory vacuum evaporator. Anti-inflammatory test was carried out on the extract.

\section{Pharmacologcal Evaluation}

Anti-inflammatory Activity:Anti-inflammatory activity will be measured using carrageenan-induced rat paw oedema assay (Writer et al., 1962; Adeyemiet al., 2002). Groups of 5 rats of both sexes (pregnant female excluded) were given a dose of a 
test compound. After one hour $0.1 \mathrm{ml}, 1 \%$ Carrageenan suspension in $0.9 \% \mathrm{NaCl}$ solution were injected into the sub-planter tissue of the right hand paw. The linear paw circumference was measured at hourly interval for four hours (Bamgbose and Noamesi 1981). Two groups of drug treated rats and one control group were used each test day and the mean paw oedema value for the test group being compared with the mean value for the control group for that day.

Anti-inflammatary activity (Duffy et al; 2001) will be measured as the percentage reduction in oedema level where drug was present, relative to control. Indomethacin $(10 \mathrm{mg} / \mathrm{kg})$ was administered orally as reference drug, whereas $10 \%$ Tween 80 was uses as negative control.

Statistical Analysis:All data were expressed as the mean + SEM, the student's t-test was applied to determine the significance of the difference between the control group and the test compounds.

\section{RESULTS AND DISCUSSION}

Previous work revealed that the methanolic extract is highly active against Gram positive, Gram negative micro-organism and fungi at concentrations of $100 \mathrm{mg} / \mathrm{mL}, 150 \mathrm{mg} / \mathrm{mL}$ and $200 \mathrm{mg} / \mathrm{mL}$ respectively. At lower concentrations of $50 \mathrm{mg} / \mathrm{mL}$, the extract shows no activity except against Candida albicans.(Osarumwenseet al., 2011).

From this study on the Anti-inflammatory activity at different doses, shows that the methanolic extract has percentage activities of $96.78 \%$ at $20 \mathrm{mg} / \mathrm{kg}$ and $95.71 \%$ at $40 \mathrm{mg} / \mathrm{kg}$, while the ethanolic extract has percentage activities of $92.26 \%$ at $20 \mathrm{mg} / \mathrm{kg}$ and $82.86 \%$ at $40 \mathrm{mg} / \mathrm{kg}$. The methanolic extract has a higher Anti-inflammatory activity than the ethanolic extract. (Table 1)

\section{Anti-inflammatory activity}

Table 1: Effects of the Extract on the Carrageenan-Induced Rat Paw Oedema

\begin{tabular}{llllllc}
\hline Extracts & $\begin{array}{l}\text { Doses(MG/KG) } \\
\text { (P.O) }\end{array}$ & \multicolumn{2}{l}{$\begin{array}{l}\text { Change in Paw } \\
\text { Oedema Mean Sem }\end{array}$} & \multicolumn{2}{c}{ \%Activity } & \multicolumn{2}{c}{$\begin{array}{l}\text { Average\%Acti } \\
\text { vity }\end{array}$} \\
\hline Methanolic & 20 & $3.28-+0.28$ & $3.73+-0.44$ & 94.82 & 96.78 & 95.80 \\
Extract & 40 & $1.33+-0.25$ & $2.80+-0.39$ & 87.22 & 95.71 & 91.47 \\
& & & & & & \\
Ethanolic & 20 & $1.25+-0.35$ & $1.53+-0.34$ & 86.40 & 92.26 & 89.33 \\
Extract & 40 & $1.05+-0.30$ & $0.70+-0.24$ & 83.81 & 82.86 & 83.34 \\
Indomethacin & 10 & $0.85+-0.30$ & $0.93+-0.37$ & 80.00 & 87.09 & 83.55 \\
Control & 0.3 & $4.62+-2.67$ & & & & \\
5\%tween & & & & & & \\
80 & & & & & & \\
\hline
\end{tabular}

Values are mean +- S.E.M $\mathrm{P}<0.001$

Significantly different from control, paired $t-\operatorname{test}(\mathrm{n}=5), \mathrm{p} . \mathrm{o}=$ per oral.

$\%$ Activity $=100-[100 \times$ (average drug treated/ average for control) $]$ Indomethacin $(10 \mathrm{mg} / \mathrm{kg}) \mathrm{was}$ administered orally as reference drug. While 5\% Tween 80 was used as negative control.

Conclussion: In conclusion, citrus sinensis peel here can be seen as a potential source of useful antiinflammatory drugs. However, further studies can be done on these peels in order to isolate, identify, and characterize the structure of the bioactive compound.

\section{REFERENCES}

Adeyemi, $\mathrm{C}$ O; Okpo, $\mathrm{S}$ O; Ogunti, C O (2002).Analgesic and anti-inflammatory effect of the aqueous extract of leaves of Persea America Mill(Lauraceae). Fitoterapia. 73. 375-380.

Akdemir,Evrendilek, G (2015). Emperical prediction and validation of antibacterial inhibitory effects of various plants essential oils on common pathogenic bacterial. Int J Food microbial. 2015: 202:35-41(pubmed).
Bamgbose, SOA; Noamesi, B K (1981). Studies on cryptolapine Inhibition of carrageenan inducedoedema by cryplolepine. Planta Med. $41,392-396$.

Duffy, J C; Dearden, J C; Rostron, C (2001). Design, Synthesis and biological testing of a novel series of anti-inflammatory drugs $J$. Pharm. Pharmacol. 53, 1505-1514.

Ezeonu, FC; Chidume, GI; Udedi, SC (2001)/ insecticidal properties of volatile extract of orange peels. Bioresour Technol. 76:273-274. 
Ezeonu, FC; Chidume, GI; Udedi, SC (2001)/ insecticidal properties of volatile extract of orange peels. Bioresour Technol. 76:273-274.

Grosso, G; Galvano, F; Mistretla, A; Marventano, S; Nolfo, F; Calabrese, G(2013) Red orange: experimental models and epidemiological evidence of its benefits on human health. Oxid red cell longer 2013: 157240 PMC Free article (pubmed)

Haiquing, J U; Robert, J; Robert; Chitang, H O. (2004). Anti-inflammatory activity of polymethoxy flavones in Sweet orande (citrus sinensis) peel and metabolites study of Nobiletin. $337-344$

Ladaniya, MS(2008) Citrus fruit Biology Technology and Evaluation. Academic press London UK. PP $1 \_11$

Mehmood, B; Dar, KK; Ali, S; Awan, UA; Nayyer, AQ; Ghous, T(2015) short communication: in vitro assessment of antioxidant, antibacterial and phytochemical analysis of peel of citrus sinensis. Pak J. pharm Sci: 2015: 28:231-9(pubmed)

Omodamiro, O D; Umekwe, J C. (2013). Evaluation of anti-inflammatory, antibacterial and antioxidant properties of ethanolic extract of Citrus sinensis peel and leaves, Journal of Chemical and Pharmaceutical Research. 5(5), $56-66$.

Osarumwense; P O; Okunrobo, L O; lmafidon, K E (2011).Phytochemical composition of Citrus sinensis (L) Osbeck and its Larvicidal and antimicrobial activity. Continental Journal of Pharmaceutical Science. 5 (1) 15 . 10/

Ortuno A, Baidez A, Gomex P, Arcas MC, Porras I, Garcia-Lidoh A, Del Rio JA(2006). Citrus paradise and citrus sinensis flavonoids: their influence in the defence mechanism against penicilliumdigitatum. Food chem. 98:351-358.

Sapne, B; Shetty; Prebu; Mahn-Syed-Ismail; ShejiVarghase; Bibin Thomas-George; PathinettamKandathl-Thajuraj; Deepak Bbby; ShaistaHaleem; SreejaSreedhar; DarshanDerang-Divakar (2016).Antimicrobial effect of citrus sinensis peel extract against dental carries bactereia. An invitro study, PMID: PMC + 739372. Doi; 104317/ced52493

Saleem, M; Farcost, A; Ahmed, S; Shalia, N; Riaz, N; Jabbar, A; Arshad, M; Malik; A(2010). Chemical constituents of citrus sinensisvarshukri from Pakistan J. Asian Hat. Prod. Res. 12-702-6

Singh, p;Shukla, R;Praksah, B; Kumar.A; Singh, S; Mishra, PK;Dubey, HK (2010) Chemical profile antifungal, antiaflatoxigenic and antioxidant activity of Citrus maxima burm, and Citrus sinensis(L) Osbeck essential oil and their cyclic monoterpene, d-limonene, food chem.. toxicol 48: 1734-1740.

Writer, C A; Risley, E A; Nuss, G W (1962).Carrageenan-induced Oedema in the hind paw of rat as an assay for anti-inflammatory activity. Procsoc. Exp. Biol. Ther. 111. 544 547. 